\title{
Massal and Individual Electrical Conductivity Tests and its Relationships with the Physiological Quality of Sweet Sorghum Seeds
}

\author{
Joner Silveira Dalcin \\ Department of Crop Science, Federal University of Santa Maria \\ Av. Roraima, 1000, Santa Maria, Brazil. E-mail: joner_dalcin@yahoo.com.br
}

Caren Alessandra Müller (Corresponding Author)

Department of Crop Science, Federal University of Santa Maria

Av. Roraima, 1000, Santa Maria, Brazil. E-mail: carenalessandra.agro@gmail.com

\section{Ubirajara Russi Nunes}

Department of Crop Science, Federal University of Santa Maria

Av. Roraima, 1000, Santa Maria, Brazil. E-mail: russinunes@yahoo.com.br

\section{Rodrigo Roso}

Department of Crop Science, Federal University of Santa Maria

Av. Roraima, 1000, Santa Maria, Brazil.

Tel: (55) 99979-6931Ｅ-mail: rodrigoroso@yahoo.com.br

Alberto Cargnelutti Filho

Department of Crop Science, Federal University of Santa Maria

Av. Roraima, 1000, Santa Maria, Brazil. E-mail: alberto.cargnelutti.filho@gmail.com

\section{Rogério Luiz Backes}

Department of Crop Science, Federal University of Santa Maria

Av. Roraima, 1000, Santa Maria, Brazil. E-mail: rogerio@backes.com.br 
Fernanda Alice Antonelo Londero Backes

Department of Crop Science, Federal University of Santa Maria

Av. Roraima, 1000, Santa Maria, Brazil. E-mail: prof.fernanda.backes@gmail.com

Luciane Almeri Tabaldi

Department of Biology, Federal University of Santa Maria

Av. Roraima, 1000, Santa Maria, Brazil. E-mail: lutabaldi@yahoo.com.br

Tiéle Stuker Fernandes

Department of Crop Science, Federal University of Santa Maria

Av. Roraima, 1000, Santa Maria, Brazil. E-mail: tielefernandes@ hotmail.com

Received: Jan. 19, 2020

doi:10.5296/jas.v8i2.16274
Accepted: Feb. 27, $2020 \quad$ Published: Mar. 4, 2020

URL: https://doi.org/10.5296/jas.v8i2.16274

\begin{abstract}
Rapid tests such as electrical conductivity provide fast and consistent results regarding stratification of seed lots by vigor. They are important tools used to evaluate the physiological quality of seeds of several species, however, no such information was found for Sorghum bicolor. The objective of this study was to evaluate the relationship between the physiological quality of the seeds by the mass and individual conductivity tests. Four plots of the Fepagro 19 cultivar were analyzed through the degree of moisture, weight of one thousand seeds, first count and germination, radicular and shoot length, dry mass, cold test and emergence of field seedlings. Subsequently, they were submitted to mass electrical conductivity experiments with variations in the imbibition time $(2,4,6,8,12$ and 24 hours), temperature (20, 25 and 30 ${ }^{\circ} \mathrm{C}$ ), number of seeds (25 and 50), volume of water (50 and $75 \mathrm{~mL}$ ) and individual $(2,4,6,8$, 12 and 24 hours). The design was completely randomized and the data evaluated by the Tukey test. Only the lowest physiological quality batch was detected in the $20{ }^{\circ} \mathrm{C}, 75 \mathrm{~mL}$ and 25 seeds for 12 hours combinations; the individual test detected the least physiological quality batch, and it was possible to perform it in 24 hours.
\end{abstract}

Keywords: tests, germination, Sorghum bicolor, vigor

\title{
1. Introduction
}

Sweet Sorghum bicolor is an alternative crop which can be grown in different regions of the country. Its sugar is stored in the stalks and provides bagasse for the industry. In addition, it 
presents some advantages such as the cultivation from seeds and a much smaller cycle in relation to sugarcane (Teixeira et al. 1997).

The physiological quality of the seeds is important for the productive sector once it provides greater security in the use of those by the time of planting (Dias \& Marcos Filho, 1996). Through the appropriate methodology, the evaluation of the physiological quality makes possible to estimate the vigor, field performance and the disposal of inferior quality lots, before they be commercialized. Thus, methods that estimate the physiological potential of lots are fundamental, since after the physiological maturity, the seeds go through continuous and irreversible processes of aging and deterioration.

The advancement of technologies and the need for high productivity, made the germination test proposed by Brasil (2009) insufficient to compose the adequate information of a seed lot. Tests that evaluate seeds vigor provide more sensitive indexes when compared to the traditional germination test (AOSA, 1983). The electrical conductivity test has been used to evaluate the seeds vigor, potential of emergence and storage of species such as soybean and wheat (Mattioni et al. 2015, Mertz et al. 2012). However, the results can be affected by some factors such as: characteristics of the seed itself (size and genotype, mechanical damage, insect injury); imbibition temperature, chemical treatment; degree of moisture, quality and volume of water (Vieira \& Krzyzanowski, 1999, Marcos Filho, 2015).

The electrical conductivity test can be conducted in a mass or individual method. Steere et al. (1981) proposed the determination of individual electric conductivity of seeds, which was developed to correct problems existing in the mass evaluation, especially in samples that contain damaged seeds or that present variations in the leaching capacity. Through this test, it was possible to classify lots of different vigor levels according to the physiological quality, as well as to determine the germination estimation on an efficient way (Mattioni et al. 2015). Although this test has already been well establish for many cultures, there are some lacking information about its application for Sorghum bicolor.

Considering this context, the objective of this work was to evaluate the physiological relationships with the quality potential of different sweet sorghum (Sorghum bicolor) seed lots through mass and individual electrical conductivity tests.

\section{Materials and Methods}

\subsection{Initial Evaluation Sorghum Bicolor Seeds}

The experiments were conducted at the didactic and seed research laboratory located at the Departamento de Fitotecnia of the Universidade Federal de Santa Maria (UFSM), in the Rio Grande do Sul state, Brazil. It was used four seed lots from Fepagro F-19 cultivar. These seeds were produced in the experimental filed of Fitotecnia (UFSM) in 2012/2013. Prior the beginning of the study, the seeds were stored in a cold chamber during a period of six months. For this reason, samples from all lots were evaluated separately for physical and physiological characteristics by performing the following tests: weight of thousand seeds, moisture content, germination test, root and shoot length, dry mass of seedlings, cold test and emergence of seedlings on field (Nakagawa, 1999, Brasil, 2009). 
2.2 Evaluation of the Physiological Quality of the Seeds by the Mass and Individual Conductivity Test

The mass conductivity test was conducted by evaluating eight replicates. Afterwards, the seeds were placed to soak in plastic containers. Variations in the number of seeds, water volume, temperature and imbibition time were applied. The number of 25 and 50 seeds was used. The volume of water used for imbibition was 50 and $75 \mathrm{~mL}$ and temperatures of 20,25 and $30{ }^{\circ} \mathrm{C}$ for 2, 4, 6, 8, 12 and 24 hours of imbibition. Then, the electrical conductivity of the imbibition solution was read, without agitation, through the calibrated model of the Digimed DM 31, previously calibrated, with a constant electrode of 1.0 and the results were expressed in $\mu \mathrm{S} \mathrm{cm}^{-1}$ $\mathrm{g}^{-1}$ (Vieira, 1994). At each reading time, the electrode was washed with deionized water and dried with paper towel in order to avoid conducting waste from one vial to the other.

The Automatic Seed Analyzer (SAD 9000-S) was used to perform the conductivity test of the solution individually. This appliance has a tray with 100 wells, with one seed per well and $5 \mathrm{ml}$ of deionized water. The trays were placed inside the B.O.D. at a constant temperature of $25^{\circ} \mathrm{C}$ and the readings performed in six imbibition periods $(2,4,6,8,12$ and 24 hours) for each lot and cultivar. The results were expressed in $\mu \mathrm{S} \mathrm{cm}^{-1} \mathrm{seed}^{-1}$ (Mattioni et al. 2015).

\subsection{Statistical Analisys}

The results of the determination of the weight of one thousand seeds and degree of humidity were not submitted to statistical analysis. A completely randomized design was used for all the tests performed. The tests to determine the physiological quality of the seeds in the initial characterization were conducted with eight replicates of 50 seeds to evaluate the lot effects.

The mass electrical conductivity experiment was performed by eight replicates in a completely randomized design. The treatments were arranged in a 4 × $3 \times 2 \times 2 \times 6$ five-factorial scheme (4 lots, 3 temperatures, 2 water volumes, 2 seed numbers and 6 imbibition periods).

The individual electrical conductivity experiment was also performed in a completely randomized design by eight replicates to evaluate the lot effects, in the 2, 4, 6, 8, 12 and 24 hours imbibition periods.

In order to attempt the assumptions of the mathematical model, the percentage results were transformed in arc-sine $\sqrt{ } \mathrm{x} / 100$. Those percentages represented the germinated seeds or normal seedlings obtained by the tests. The data were submitted to analysis of variance and F- Test to $5 \%$ error probability and the means were compared by the Tukey test $(p<0.05)$ by Sisvar® Software (Ferreira, 2011).

\section{Results and Discussion}

The data from the initial characterization for F-19 cultivar are presented in Table 1. The data referent to the weight of thousand seed and moisture content were not statistically analyzed. There was a consistent uniformity on moisture content with a small variation of 0.68 percentage points, which means that the variability between the lots was low. There was a significative difference for cold test (CT) and radicle length (RL) between the lots. Lot 3 presented the best 
physiological quality, followed by lots 1 and 2, and lot 4 , which presented the lower quality.

Table 1. Initial characterization of sweet sorghum seeds with moisture content (MC), 1000-seed weight, percentage seed germination (PG), first count of germination (FC), cold test (CT), epicotyl length (EL), radicle length (RL), dry mass (DM), emergence of seedlings on field (ESF) of four lots of F-19 cultivar

\begin{tabular}{cccccccccc}
\hline Seed lot & $\begin{array}{c}\text { MC } \\
(\%)\end{array}$ & $\begin{array}{c}\text { 1000-seed } \\
\text { weight }(\mathrm{g})\end{array}$ & $\begin{array}{c}\text { PG } \\
(\%)\end{array}$ & $\begin{array}{c}\text { FC } \\
(\%)\end{array}$ & $\begin{array}{c}\text { CT } \\
(\%)\end{array}$ & $\begin{array}{c}\text { EL } \\
(\mathrm{cm})\end{array}$ & $\begin{array}{c}\text { RL } \\
(\mathrm{cm})\end{array}$ & $\begin{array}{c}\text { DM } \\
(\mathrm{g})\end{array}$ & $\begin{array}{c}\text { ESF } \\
(\%)\end{array}$ \\
\hline 1 & 13.24 & 20.07 & $91 \mathrm{a}$ & $86 \mathrm{a}$ & $86 \mathrm{ab}$ & $7.42 \mathrm{a}$ & $13.95 \mathrm{ab}$ & $1.44 \mathrm{a}$ & $85 \mathrm{a}$ \\
2 & 13.15 & 19.41 & $89 \mathrm{a}$ & $82 \mathrm{a}$ & $81 \mathrm{ab}$ & $6.83 \mathrm{a}$ & $14.30 \mathrm{ab}$ & $1.55 \mathrm{a}$ & $85 \mathrm{a}$ \\
3 & 12.89 & 20.08 & $90 \mathrm{a}$ & $87 \mathrm{a}$ & $88 \mathrm{a}$ & $7.33 \mathrm{a}$ & $14.98 \mathrm{a}$ & $1.51 \mathrm{a}$ & $85 \mathrm{a}$ \\
4 & 12.86 & 19.78 & $87 \mathrm{a}$ & $83 \mathrm{a}$ & $80 \mathrm{~b}$ & $6.99 \mathrm{a}$ & $13.63 \mathrm{~b}$ & $1.54 \mathrm{a}$ & $81 \mathrm{a}$ \\
\hline \multirow{2}{*}{ Mean } & & & 90 & 85 & 84.1 & 7.1 & 14.2 & 1.5 & 83.9 \\
\hline C.V.(\%) & & & 4.99 & 6.10 & 6.38 & 9.40 & 6.60 & 7.60 & 6.15 \\
\hline
\end{tabular}

*Means followed by the same letter in the column do not differ by Tukey test, $\mathrm{p}<0.05$

Tables 2 to 4 presents the results of mass conductivity test. Commonly, the quality evaluation of a seed lot is compared between the results found in the initial characterization of the seeds and the vigor test. Therefore, it is possible to notice statistical differences in the physiological quality of the lots and some variables on the mass conductivity test. Still, the results which were more similar to the values of the initial characterization, were obtained with the combination of $20^{\circ} \mathrm{C}, 75 \mathrm{~mL}, 25$ seeds from 12 to 24 hours of imbibition.

These were the variables that had the greatest relationship with cold and root length tests (Table 1), in which provided the classification of lot 3 with better physiological quality and lot 4 with lower. Similarly, the values of mass electrical conductivity in these combinations showed that lot 3 presented the lowest value of electrical conductivity and lot 4 the higher value, thus, there was a relationship between the initial characterization tests with the mass electrical conductivity test for stratification of seed lots by its physiological quality.

The other combinations employed do not demonstrated relationship with the initial characterization tests. Although there were significant differences among the lots in some variables, these differences did not provided the same stratification of the lots in relation to the physiological quality obtained on the initial tests. However, Alves and Sá (2009) identified that after 4 hours of imbibition there was difference between the lots for arugula seeds. This shows that the results can be very different depending on the species (sorghum, saccharine, forage, etc.) and even different cultivars, since the genetics of each material is unique.

The confirmation of the lot of lower physiological potential was clearer, compared to the lot of higher physiological quality. Probably the identification of the lot of higher physiological quality was not evident, because in the initial characterization it can be observed that lots 1,2 and 3, were very similar and only lot 4 presented lower physiological quality, different from 
the other lots. The same occurred in the mass electrical conductivity test, which was efficient on the identification of the lot of low physiological potential. Similar results were found by Silva et al. (2014) using the same method, who observed on whole bean seeds the stratification of the lots after five hours of immersion, however, when using only cotyledons the time of the test could be reduced, with the same efficiency, in two hours.

Therefore, the test can be influenced by several variables that can change the results significantly, since the evaluation is through the leachate in the solution. For example, Machado et al. (2011) determined through the electrical conductivity test that the volume of $250 \mathrm{~mL}$ of water and temperature of $25{ }^{\circ} \mathrm{C}$ for 24 hours was promising for the differentiation of seed lots of peas, which was a higher volume of water than the applied on our study.

Table 5 shows the means values of individual electrical conductivity using 2, 4, 6, 8, 12 and 24 hours of imbibition at $25^{\circ} \mathrm{C}$. It can be noticed that the test is very sensitive and shows difference between the lots after only two hours of imbibition.

Table 2. Mass electrical conductivity means $\left(\mu \mathrm{S} \mathrm{cm}^{-1} \mathrm{~g}^{-1}\right)$ using the combinations $2,4,6,8,12$ and 24 hours imbibition time, number of seeds of 25 and 50 seeds and volume of water of 50 and $75 \mathrm{~mL}$ at the temperature of $20^{\circ} \mathrm{C}$, respectively, in four lots of sorghum seeds for $\mathrm{F}-19$ cultivar

\begin{tabular}{|c|c|c|c|c|c|c|}
\hline \multicolumn{7}{|c|}{ Period of imbibition (hours) } \\
\hline Seed lot & 2 & 4 & 6 & 8 & 12 & 24 \\
\hline \multicolumn{7}{|c|}{$50 \mathrm{~mL} / 25$ seeds } \\
\hline 1 & $22.3 \mathrm{a}$ & $26.8 \mathrm{~b}$ & $30.3 \mathrm{~b}$ & $33.7 \mathrm{~b}$ & $37.0 \mathrm{~b}$ & $44.5 \mathrm{c}$ \\
\hline 2 & $23.6 \mathrm{a}$ & $33.3 \mathrm{a}$ & $38.5 \mathrm{a}$ & $40.9 \mathrm{a}$ & $46.3 \mathrm{a}$ & $56.4 \mathrm{a}$ \\
\hline 3 & $22.1 \mathrm{a}$ & $26.7 \mathrm{~b}$ & $30.9 \mathrm{~b}$ & $34.5 \mathrm{~b}$ & $37.3 \mathrm{~b}$ & $44.8 \mathrm{bc}$ \\
\hline 4 & $23.3 \mathrm{a}$ & $27.9 \mathrm{~b}$ & $33.1 \mathrm{~b}$ & $36.2 \mathrm{~b}$ & $40.5 \mathrm{~b}$ & $49.1 \mathrm{~b}$ \\
\hline \multicolumn{7}{|c|}{$50 \mathrm{~mL} / 50$ seeds } \\
\hline 1 & $12.9 \mathrm{a}$ & $18.6 \mathrm{a}$ & $23.1 \mathrm{~b}$ & $25.1 \mathrm{~b}$ & $29.4 \mathrm{~b}$ & $35.9 \mathrm{~b}$ \\
\hline 2 & $12.1 \mathrm{a}$ & $22.2 \mathrm{a}$ & $26.8 \mathrm{ab}$ & $29.1 \mathrm{ab}$ & $33.1 \mathrm{ab}$ & $40.3 \mathrm{ab}$ \\
\hline 3 & $12.1 \mathrm{a}$ & $21.6 \mathrm{a}$ & $25.8 \mathrm{ab}$ & $28.8 \mathrm{ab}$ & $32.5 \mathrm{ab}$ & $40.1 \mathrm{ab}$ \\
\hline 4 & $12.3 \mathrm{a}$ & $22.7 \mathrm{a}$ & $27.8 \mathrm{a}$ & $30.3 \mathrm{a}$ & $34.8 \mathrm{a}$ & $42.4 \mathrm{a}$ \\
\hline \multicolumn{7}{|c|}{$75 \mathrm{~mL} / 25$ seeds } \\
\hline 1 & $10.1 \mathrm{a}$ & $16.7 \mathrm{a}$ & $19.9 \mathrm{a}$ & $22.6 \mathrm{a}$ & $24.9 \mathrm{ab}$ & $30.3 \mathrm{ab}$ \\
\hline 2 & $11.4 \mathrm{a}$ & $18.5 \mathrm{a}$ & $22.4 \mathrm{a}$ & $24.6 \mathrm{a}$ & $27.8 \mathrm{a}$ & $32.7 \mathrm{a}$ \\
\hline 3 & $9.6 \mathrm{a}$ & $16.4 \mathrm{a}$ & $18.5 \mathrm{a}$ & $20.4 \mathrm{a}$ & $23.1 \mathrm{~b}$ & $27.1 \mathrm{~b}$ \\
\hline 4 & $9.8 \mathrm{a}$ & $17.9 \mathrm{a}$ & $21.3 \mathrm{a}$ & $24.6 \mathrm{a}$ & $28.3 \mathrm{a}$ & $33.3 \mathrm{a}$ \\
\hline \multicolumn{7}{|c|}{$75 \mathrm{~mL} / 50$ seeds } \\
\hline 1 & $6.2 \mathrm{a}$ & $10.9 \mathrm{a}$ & $13.9 \mathrm{a}$ & $15.7 \mathrm{a}$ & $17.7 \mathrm{~b}$ & $22.6 \mathrm{~b}$ \\
\hline 2 & $7.0 \mathrm{a}$ & $12.8 \mathrm{a}$ & $16.7 \mathrm{a}$ & $19.6 \mathrm{a}$ & $22.9 \mathrm{a}$ & $27.5 \mathrm{a}$ \\
\hline 3 & $7.1 \mathrm{a}$ & $13.2 \mathrm{a}$ & $17.1 \mathrm{a}$ & $19.7 \mathrm{a}$ & $23.1 \mathrm{a}$ & $28.2 \mathrm{a}$ \\
\hline 4 & $6.2 \mathrm{a}$ & $12.3 \mathrm{a}$ & $16.3 \mathrm{a}$ & $19.2 \mathrm{a}$ & $23.3 \mathrm{a}$ & $29.2 \mathrm{a}$ \\
\hline
\end{tabular}

*Means followed by the same letter in the column do not differ by Tukey test, $\mathrm{p}<0.05$ 
In the initial characterization, by the tests of cold and radicle length, lot 4 had the lowest physiological quality (Table 1), and other lots were very similar. Analyzing these data, it is verified that in the individual electrical conductivity test (Table 5), the highest value of electrical conductivity was in lot 4 . This fact demonstrates the sensitivity of the test in discriminating the lot of lower physiological quality. The same was not observed for the lot with the highest physiological potential, probably due to the similarity between the lots, as evidenced by the statistical analysis. The same fact has occurred on the study of Soares et al. (2010), where it was possible to discriminated only the lower quality lot, when using the mass electrical conductivity test in forage sorghum seeds, with 2, 4 and 6 hours of imbibition in $75 \mathrm{~mL}$ of water, in 16 hours of imbibition, in $50 \mathrm{~mL}$ of water.

Table 3. Mass electrical conductivity means $\left(\mu \mathrm{S} \mathrm{m}^{-1} \mathrm{~g}^{-1}\right)$ using the combinations $2,4,6,8$, 12 and 24 hours imbibition time, number of seeds of 25 and 50 seeds and volume of water of 50 and $75 \mathrm{~mL}$ at the temperature of $25^{\circ} \mathrm{C}$, respectively, in four lots of sorghum seeds for F-19 cultivar

\begin{tabular}{ccccccc}
\hline \multicolumn{7}{c}{ Period of imbibition (hours) } \\
\hline Seed lot & 2 & 4 & 6 & 8 & 12 & 24 \\
\hline 1 & $15.4 \mathrm{a}$ & $24.6 \mathrm{~b}$ & $30.4 \mathrm{~b}$ & $34.8 \mathrm{~b}$ & $40.2 \mathrm{~b}$ & $47.2 \mathrm{c}$ \\
2 & $16.6 \mathrm{a}$ & $27.0 \mathrm{ab}$ & $33.8 \mathrm{ab}$ & $37.9 \mathrm{ab}$ & $44.7 \mathrm{ab}$ & $54.2 \mathrm{ab}$ \\
3 & $17.6 \mathrm{a}$ & $29.4 \mathrm{a}$ & $35.0 \mathrm{a}$ & $39.0 \mathrm{ab}$ & $45.4 \mathrm{a}$ & $52.2 \mathrm{~b}$ \\
4 & $19.4 \mathrm{a}$ & $30.5 \mathrm{a}$ & $36.6 \mathrm{a}$ & $41.4 \mathrm{a}$ & $49.1 \mathrm{a}$ & $58.2 \mathrm{a}$ \\
\hline \multicolumn{7}{c}{$50 \mathrm{~mL} / 50 \mathrm{seeds}$} \\
\hline 1 & $9.6 \mathrm{a}$ & $15.9 \mathrm{a}$ & $21.2 \mathrm{~b}$ & $25.0 \mathrm{~b}$ & $28.3 \mathrm{c}$ & $35.2 \mathrm{c}$ \\
2 & $8.5 \mathrm{a}$ & $17.4 \mathrm{a}$ & $24.4 \mathrm{ab}$ & $31.0 \mathrm{a}$ & $36.1 \mathrm{ab}$ & $44.5 \mathrm{~b}$ \\
3 & $10.9 \mathrm{a}$ & $18.1 \mathrm{a}$ & $26.0 \mathrm{a}$ & $29.9 \mathrm{a}$ & $34.0 \mathrm{~b}$ & $41.7 \mathrm{~b}$ \\
4 & $11.5 \mathrm{a}$ & $18.4 \mathrm{a}$ & $28.2 \mathrm{a}$ & $33.1 \mathrm{a}$ & $39.4 \mathrm{a}$ & $49.4 \mathrm{a}$ \\
\hline \multicolumn{7}{c}{$75 \mathrm{~mL} / 25 \mathrm{seeds}$} \\
\hline 1 & $9.1 \mathrm{a}$ & $14.4 \mathrm{a}$ & $16.8 \mathrm{~b}$ & $19.2 \mathrm{~b}$ & $21.8 \mathrm{~b}$ & $27.0 \mathrm{c}$ \\
2 & $11.2 \mathrm{a}$ & $18.9 \mathrm{a}$ & $23.5 \mathrm{a}$ & $26.3 \mathrm{a}$ & $29.4 \mathrm{a}$ & $39.4 \mathrm{a}$ \\
3 & $9.3 \mathrm{a}$ & $16.5 \mathrm{a}$ & $20.3 \mathrm{ab}$ & $22.8 \mathrm{ab}$ & $24.9 \mathrm{ab}$ & $31.4 \mathrm{bc}$ \\
4 & $10.8 \mathrm{a}$ & $17.0 \mathrm{a}$ & $21.0 \mathrm{ab}$ & $23.6 \mathrm{ab}$ & $27.5 \mathrm{a}$ & $34.6 \mathrm{~b}$ \\
\hline \multicolumn{7}{c}{$75 \mathrm{~mL} / 50 \mathrm{seeds}$} \\
\hline 1 & $10.2 \mathrm{a}$ & $14.1 \mathrm{a}$ & $16.8 \mathrm{a}$ & $19.8 \mathrm{a}$ & $22.9 \mathrm{a}$ & $28.5 \mathrm{a}$ \\
2 & $9.0 \mathrm{a}$ & $14.7 \mathrm{a}$ & $18.3 \mathrm{a}$ & $21.1 \mathrm{a}$ & $24.1 \mathrm{a}$ & $30.8 \mathrm{a}$ \\
3 & $11.5 \mathrm{a}$ & $15.2 \mathrm{a}$ & $19.3 \mathrm{a}$ & $21.8 \mathrm{a}$ & $24.5 \mathrm{a}$ & $30.9 \mathrm{a}$ \\
\hline & $12.3 \mathrm{a}$ & $15.7 \mathrm{a}$ & $19.6 \mathrm{a}$ & $22.2 \mathrm{a}$ & $25.1 \mathrm{a}$ & $32.1 \mathrm{a}$ \\
\hline
\end{tabular}

C.V. $(\%)=13.24$

*Means followed by the same letter in the column do not differ by Tukey test, $\mathrm{p}<0.05$

The results obtained in our study, suggest that the use of discrepant lots in terms of physiological quality may assist in routine laboratories, offering a more reliable comparative in the stratification results. These results corroborate with Mertz et al. (2012) evaluating 
wheat seeds by the individual electrical conductivity test, which pointed that after 3 hours of imbibition the test was efficient in evaluating the physiological quality potential of wheat seeds, showing the differences between the lots.

The coefficients of variation were high, in the same way, Barbieri et al. (2013) also found high values for wheat seeds, most probably as a function of the distance from the mean values, which may increase the causes of variation in the statistical analysis, but did not compromise the test result. These variations are probably related to the fact that the test is carried out individually in each seed, and small variations in seed quality, such as mechanical damages, result in higher values of electrical conductivity in the solution and, consequently, generate discrepant values that contribute to the increase observed in the statistical analysis.

Table 4. Mass electrical conductivity means $\left(\mu \mathrm{S} \mathrm{cm}^{-1} \mathrm{~g}^{-1}\right)$ using the combinations $2,4,6,8$, 12 and 24 hours imbibition time, number of seeds of 25 and 50 seeds and volume of water of 50 and $75 \mathrm{~mL}$ at the temperature of $30^{\circ} \mathrm{C}$, respectively, in four lots of sorghum seeds for F-19 cultivar

\begin{tabular}{ccccccc}
\hline \multicolumn{7}{c}{ Period of imbibition (hours) } \\
\hline Seed lot & 2 & 4 & 6 & 8 & 12 & 24 \\
\hline 1 & $16.9 \mathrm{~b}$ & $23.2 \mathrm{~b}$ & $28.0 \mathrm{~b}$ & $31.1 \mathrm{c}$ & $36.7 \mathrm{c}$ & $50.8 \mathrm{c}$ \\
2 & $22.5 \mathrm{a}$ & $30.2 \mathrm{a}$ & $36.1 \mathrm{a}$ & $40.5 \mathrm{a}$ & $46.4 \mathrm{a}$ & $63.1 \mathrm{a}$ \\
3 & $20.4 \mathrm{ab}$ & $26.5 \mathrm{ab}$ & $31.5 \mathrm{ab}$ & $34.5 \mathrm{bc}$ & $39.3 \mathrm{bc}$ & $52.8 \mathrm{bc}$ \\
4 & $20.6 \mathrm{ab}$ & $27.4 \mathrm{ab}$ & $32.2 \mathrm{ab}$ & $35.8 \mathrm{~b}$ & $41.5 \mathrm{~b}$ & $55.8 \mathrm{~b}$ \\
\hline \multicolumn{7}{c}{$50 \mathrm{~mL} / 50 \mathrm{seeds}$} \\
\hline 1 & $14.2 \mathrm{~b}$ & $21.2 \mathrm{~b}$ & $26.2 \mathrm{c}$ & $28.8 \mathrm{c}$ & $33.1 \mathrm{~b}$ & $44.1 \mathrm{c}$ \\
2 & $18.3 \mathrm{ab}$ & $26.4 \mathrm{a}$ & $32.6 \mathrm{ab}$ & $37.3 \mathrm{ab}$ & $42.9 \mathrm{a}$ & $58.6 \mathrm{a}$ \\
3 & $18.2 \mathrm{ab}$ & $25.4 \mathrm{ab}$ & $30.5 \mathrm{bc}$ & $33.9 \mathrm{~b}$ & $37.3 \mathrm{~b}$ & $49.3 \mathrm{~b}$ \\
4 & $20.3 \mathrm{a}$ & $29.3 \mathrm{a}$ & $35.9 \mathrm{a}$ & $40.4 \mathrm{a}$ & $46.1 \mathrm{a}$ & $60.9 \mathrm{a}$ \\
\hline \multicolumn{7}{c}{$75 \mathrm{~mL} / 25 \mathrm{seeds}$} \\
\hline 1 & $10.3 \mathrm{a}$ & $15.3 \mathrm{a}$ & $19.0 \mathrm{~b}$ & $21.9 \mathrm{~b}$ & $25.5 \mathrm{~b}$ & $35.1 \mathrm{~b}$ \\
2 & $12.8 \mathrm{a}$ & $19.3 \mathrm{a}$ & $23.5 \mathrm{a}$ & $26.7 \mathrm{a}$ & $31.8 \mathrm{a}$ & $43.4 \mathrm{a}$ \\
3 & $12.0 \mathrm{a}$ & $16.8 \mathrm{a}$ & $20.4 \mathrm{ab}$ & $22.9 \mathrm{ab}$ & $26.9 \mathrm{~b}$ & $36.3 \mathrm{a}$ \\
4 & $13.1 \mathrm{a}$ & $18.9 \mathrm{a}$ & $23.8 \mathrm{a}$ & $26.9 \mathrm{a}$ & $32.6 \mathrm{a}$ & $43.6 \mathrm{a}$ \\
\hline \multicolumn{7}{c}{$75 \mathrm{~mL} / 50 \mathrm{seeds}$} \\
\hline 1 & $9.2 \mathrm{a}$ & $14.1 \mathrm{a}$ & $17.8 \mathrm{~b}$ & $21.2 \mathrm{~b}$ & $25.8 \mathrm{~b}$ & $33.7 \mathrm{~b}$ \\
\hline & $12.1 \mathrm{a}$ & $17.3 \mathrm{a}$ & $21.9 \mathrm{ab}$ & $25.5 \mathrm{ab}$ & $30.9 \mathrm{a}$ & $41.4 \mathrm{a}$ \\
4 & $11.7 \mathrm{a}$ & $17.3 \mathrm{a}$ & $21.6 \mathrm{ab}$ & $24.2 \mathrm{ab}$ & $29.3 \mathrm{ab}$ & $39.2 \mathrm{a}$ \\
\hline & $12.8 \mathrm{a}$ & $18.5 \mathrm{a}$ & $23.1 \mathrm{a}$ & $26.7 \mathrm{a}$ & $32.2 \mathrm{a}$ & $42.4 \mathrm{a}$ \\
\hline
\end{tabular}

C.V. $(\%)=13.24$

*Means followed by the same letter in the column do not differ by Tukey test, $\mathrm{p}<0.05$

However, recently promising results are not always found in the literature for all crops. Souza et al. (2009) evaluating castor bean seeds did not find any relation between the tests that compose the initial seed quality and the individual electrical conductivity test. So, there was 
no efficiency of the test in distinguishing the lots from the potential of physiological quality according to the methodology used in the study, with only 2, 4 and 6 hours of imbibition of the seeds in the solution, a fact that may explain the non-detection of differences between the lots.

Table 5. Individual electrical conductivity means $\left(\mu \mathrm{S} \mathrm{cm}^{-1} \mathrm{seed}^{-1}\right)$ in four sorghum seed lots, using the combinations of $2,4,6,8,12$ and 24 hours imbibition time at the temperature of $25^{\circ} \mathrm{C}$ in four lots of sorghum seeds for F-19 cultivar

\begin{tabular}{ccccccc}
\hline \multicolumn{7}{c}{ Period of imbibition (hours) } \\
\hline Seed lot & 2 & 4 & 6 & 8 & 12 & 24 \\
\cline { 2 - 7 } 1 & $0.29 \mathrm{~b}$ & $0.74 \mathrm{c}$ & $1.22 \mathrm{c}$ & $2.10 \mathrm{~b}$ & $2.26 \mathrm{c}$ & $4.10 \mathrm{c}$ \\
2 & $0.72 \mathrm{ab}$ & $1.72 \mathrm{~b}$ & $2.93 \mathrm{ab}$ & $3.76 \mathrm{ab}$ & $4.76 \mathrm{ab}$ & $7.71 \mathrm{ab}$ \\
3 & $0.62 \mathrm{ab}$ & $1.51 \mathrm{~b}$ & $2.42 \mathrm{~b}$ & $3.90 \mathrm{a}$ & $4.05 \mathrm{bc}$ & $6.86 \mathrm{~b}$ \\
4 & $0.98 \mathrm{a}$ & $2.54 \mathrm{a}$ & $3.96 \mathrm{a}$ & $4.81 \mathrm{a}$ & $6.25 \mathrm{a}$ & $9.29 \mathrm{a}$ \\
\hline $\mathrm{CV}(\%)$ & 53.86 & 34.30 & 32.94 & 34.59 & 31.22 & 23.91 \\
\hline
\end{tabular}

*Means followed by the same letter in the column do not differ by Tukey test, $\mathrm{p}<0.05$

The speedy that these tests can provide information on the physiological quality of the seed lot can be variable, depending very much on the species, type of seed structure and lot quality. Therefore, different results of the variables are successfully found for lot stratification. Torres et al. (2015) achieved efficiency for the evaluation of the physiological potential of coriander seeds after only two hours of imbibition. Other studies use whole seeds, embryonic axes or cotyledons, such as Silva et al. (2014) in bean seeds, where it was possible to only identify the lot of higher physiological quality.

\section{Conclusion}

The mass and individual electrical conductivity tests were efficient in detecting the lot of lower physiological quality, especially at the temperature of $20{ }^{\circ} \mathrm{C}, 75 \mathrm{~mL}$ and 25 seeds during 24 hours of imbibition in F-19 cultivar sorghum seeds.

The use of discrepant lots regarding the physiological quality may help in the comparison between the electrical conductivity test and the tests that compose the initial characterization.

\section{Acknowledgement}

CNPQ - the PQ productivity scholarship teacher researcher Dr. Ubirajara Russi Nunes.

\section{References}

Alves, C. Z., \& Sá, M. E. de (2009). Teste de condutividade elétrica na avaliação do vigor de sementes de rúcula. Revista Brasileira de Sementes, 31(1), 203-215. https://doi.org/10.1590/S0101-31222009000100023

AOSA, (Association of Official Seed Analysts) (1983). (ed). Seed vigor testing handbook. Contribution n. 32 to the Handbook on Seed Testing, 88p.

Barbieri, A. P. P., Mattioni, N. M., Haesbaert, F. M., Andrade, F. F. de, Cabrera, I. C., \& 
Mertz, L. M. (2013). Teste de condutividade elétrica individual em sementes de soja e a relação com emergência de plântulas. Interciencia, 38(4), 310-315. https://www.interciencia.net/wp-content/uploads/2017/12/310-c-BARBIERI-6.pdf

Brasil. Ministério da Agricultura, Pecuária e Abastecimento (2009). Regras para análise de sementes / Ministério da Agricultura, Pecuária e Abastecimento. Secretaria de Defesa Agropecuária.-Brasília:Mapa/ACS, 399

p. http://www.agricultura.gov.br/assuntos/insumos-agropecuarios/arquivos

Dias, D. C. F. S., \& Marcos Filho, J. (1996). Testes de condutividade elétrica para avaliação do vigor de sementes de soja (Glycine max (L,) Merrill). Scientia Agrícola, 53(1), 1-11. https://doi.org/10.1590/S0103-90161996000100005

Ferreira, D. F. (2011). Sisvar: a computer statistical analysis system. Ciência e Agrotecnologia, 35(6), 1039-1042. https://doi.org/10.1590/S1413-70542011000600001

Machado, C. G., Martins, C. C., Santana, D. G. de, Cruz, S. C. S., \& Oliveira, S. S. C. de (2011). Adequação do teste de condutividade elétrica para sementes de Pisum sativum subsp. Arvense. Ciência Rural, 41(6), 988-995. https://doi.org/10.1590/S0103-84782011005000062

Marcos Filho, J. (2015) Fisiologia de sementes de plantas cultivadas. Londrina: ABRATES, $659 \mathrm{p}$.

Mattioni, N. M., Mertz, L. M., Barbieri, A. P. P., Haesbaert, F. M., Giordani, W., \& Lopes, S. J. (2015). Individual electrical conductivity test for the assessment of soybean seed germination. Semina: Ciências Agrárias, 36(1), 31-38. https://doi.org/10.5433/1679-0359.2015v36n1p31

Mertz, L. M., Segalin, S. R., Huth, C., \& Rosa, T. D. A. (2012). Condutividade elétrica individual para a avaliação do potencial fisiológico de sementes de trigo. Informativo ABRATES, 22(1),

22(1), 35-39. https://www.yumpu.com/pt/document/read/12951079/condutividade-eletrica-individual-paraa-avaliacao-do-abrates

Nakagawa, J. (1999). Testes de vigor baseados na avaliação das plântulas. In: Krzyzanowski, F. C., Vieira, R. D., França Neto, J. B. (Ed.). Vigor de sementes: conceitos e testes. Londrina: ABRATES.

Silva, V. N., Zambiasi, C. A., Tillmann, M. A. A., Menezes, N. L., \& Villela, F. A. (2014). Condução do teste de condutividade elétrica utilizando partes de sementes de feijão. Revista de Ciências Agrárias, 206-213. http://www.scielo.mec.pt/scielo.php?script=sci_arttext\&pid=S0871-018X2014000200011

Soares, M. M., Conceição, P. M. da, Dias, D. C. F. S., \& Alvarenga, E. M. (2010). Testes para avaliação do vigor de sementes de sorgo com ênfase à condutividade elétrica. Ciência e Agrotecnologia, 34(2), 391-397. https://doi.org/10.1590/S1413-70542010000200017

Souza, L. A., Carvalho, M. L. M., Kataoka, V. Y., \& Oliveira, J. A. de (2009). Teste de condutividade elétrica para avaliação da qualidade fisiológica de sementes de mamona. 
Revista Brasileira de Sementes, 31(1), 60-67. https://doi.org/10.1590/S0101-31222009000100007

Steere, W. C.; Levengoog, W. C.; \& Bondie, J. M. (1981). An electronic analyser for evaluating seed germination and vigour. Seed Science and Technology, 9(2), 567-576. http://agris.fao.org/agris-search/search.do?recordID=XE8182696

Teixeira, C. G., Jardine, J. G., \& Beisman, D. A. (1997). Utilização do sorgo sacarino como matéria-prima complementar à cana-de-açúcar para obtenção de etanol em microdestilaria. $\begin{array}{lllll}\text { Ciência } e \text { Tecnologia de Alimentos, } & \text { 17(3), }\end{array}$ https://doi.org/10.1590/S0101-20611997000300011

Torres, S. B., Paiva, E. P. de, Almeida, J. P. N. de, Benedito, C. P., \& Carvalho, S. M. C. (2015). Teste de condutividade elétrica na avaliação da qualidade fisiológica de sementes de coentro. Revista Ciência Agronômica, 46(3) 622-629.

https://doi.org/10.5935/1806-6690.20150046

Vieira, R. D. (1994). Teste de condutividade elétrica. In: Vieira, R. D.; Carvalho, N. M. Testes de vigor em sementes. Jaboticabal: Funep, p. 103-139.

Vieira, R. D., \& Krzyzanowski, F. C. (1999). Teste de condutividade elétrica. In: Krzyzanowski, F. C., Vieira, R. D., França Neto, J. B. (Ed.). Vigor de sementes: conceitos e testes. Brasília: ABRATES, (4), 1-26.

\section{Copyright Disclaimer}

Copyright for this article is retained by the author(s), with first publication rights granted to the journal.

This is an open-access article distributed under the terms and conditions of the Creative Commons Attribution license (http://creativecommons.org/licenses/by/4.0/). 